\title{
20
}

\section{Design for Liveability in Tropical Australia}

\author{
Lisa Law, Shokhida Safarova, Andrew Campbell \\ and Edward Halawa
}

\begin{abstract}
The ABS [Australian Bureau of Statistics] predicts a high population figure of 62.2 million Australians by 2101. This represents an extra $39,402,415$ people. To accommodate these extra millions, we would need over 17 million houses-some $14,276 \mathrm{~km}^{2}$ of new suburbia ... Despite the likelihood of such growth, Australia's current collection of major city planning frameworks only accounts for about an extra 5.5 million people. (Weller \& Bolleter, 2013, p. vi)
\end{abstract}

In their agenda-setting book on the future of Australia cities, Weller and Bolleter (2013) contemplated Australia's rapid and continual growth and its implications for the future Australian landscape. Setting views about a Big Australia to one side, these trends present Australian cities with some immutable challenges. Will Australians have to adapt to a deteriorating quality of life as cities accommodate this growth? Will the extra accommodation be built in the precincts where jobs are concentrated? Can cities grow to quarter more and more people without losing their liveability? ${ }^{1}$ Are there any special issues to consider in tropical Australia, a region that has experienced high population growth over the past decade and where the government has earmarked future development (Australian Government, 2014)?

1 The term 'liveability' is understood here as 'the quality of urban life that is determined predominantly by the physical nature of the built environment' (see State of the Environment 2011 Committee, 2011). 
Australia is not alone in facing an expanding urban footprint. Growing rapidly from 746 million people in 1950 to 3.9 billion people in 2014, the world's urban population is now expected to surpass 6 billion by 2045 (United Nations, 2014). As Rob Adams (2011), Director of City Design in Melbourne, put it, 'We are going to have to build almost as much urbanism again in the next 40 or 50 years as we have since the start of civilization'. In a context of scarce resources and climate change, designing and managing sustainable, ecologically sensitive cities is a crucial global challenge for the next century. We need to adapt locally relevant good urban design to create better cities- to minimise energy use and net greenhouse gas emissions but also to improve physical and mental health and social outcomes for urban dwellers.

In Northern Australia - a region that encompasses the parts of Australia north of the Tropic of Capricorn, including parts of Western Australia, the Northern Territory and Queensland-new suburban development to accommodate growing populations only rarely follows principles of sustainable tropical design (cf. Bay \& Ong, 2006; Emmanuel, 1995; Safarova et al., 2017; Safarova et al., 2018). New subdivisions tend to offer large concrete block dwellings with many internal walls and small window openings, with tiny backyard/green spaces that are often enclosed with a substantial fence (see, for example, Figure 20.1; Law, 2019). Small backyards prohibit landscaping for shading buildings and reducing ambient temperatures, fencing prohibits breezeways and the block homes themselves need air conditioning for a large portion of the year. Such subdivisions tend to have poor environmental and social outcomes, with residents retreating to the climate-controlled privacy of their home. Australian New Urbanism has made some headway in planning circles, creating more diverse and walkable communities with better access to green/public spaces. Urban consolidation projects have also tended to encourage smaller lot sizes to enable higher urban densities (Hall, 2010). Most new subdivisions in cities and towns across tropical Australia are consequently energy hungry and overly reliant on car use. 


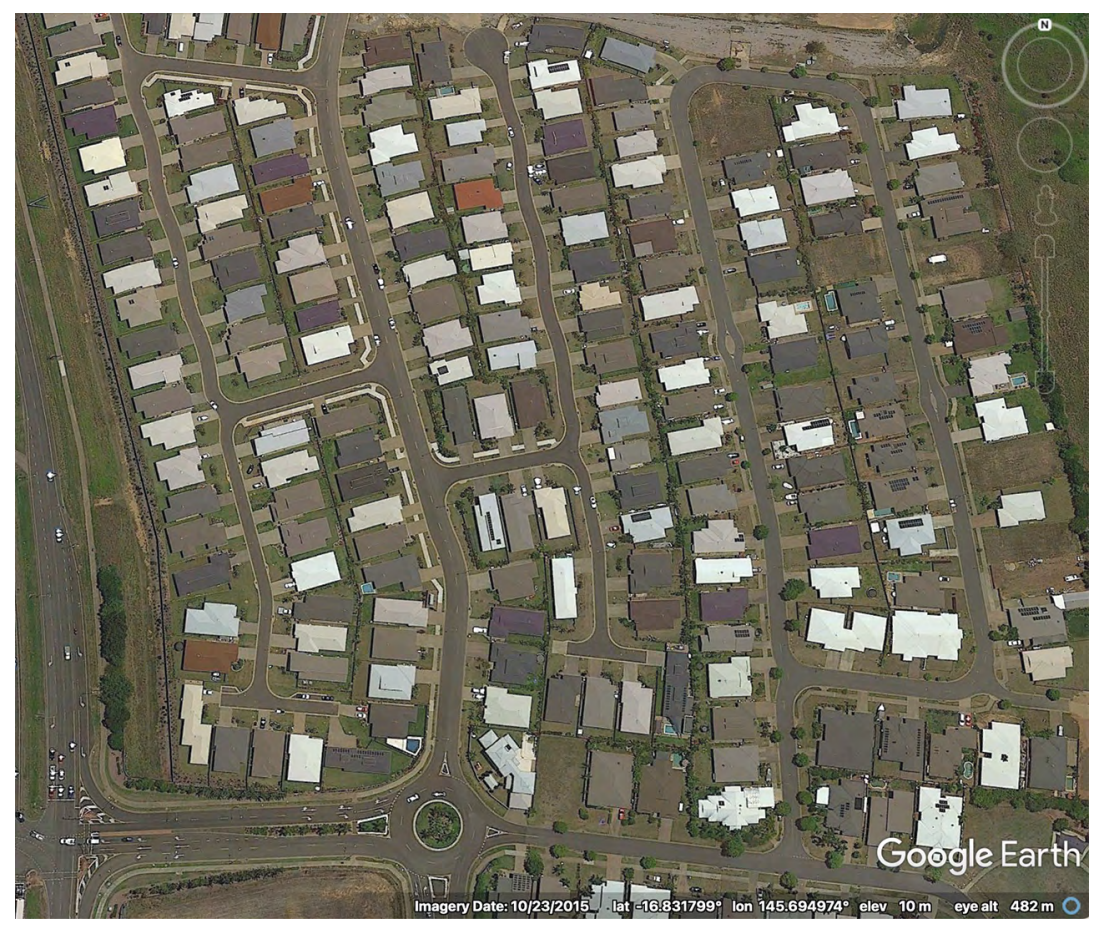

Figure 20.1: Google Earth image of a tightly packed, air-conditioned neighbourhood in Cairns (16 August 2016).

Source: Google Earth.

Therefore, urban growth and consolidation presents urban designers and architects in Northern Australia with unique challenges in terms of creating habitable/comfortable indoor and outdoor spaces. The main design challenge is to reconcile two opposing thermal comfort parameters in a hot and humid tropical climate characterised by a high ambient air temperature and high relative humidity. On one hand is the need for ventilation and air movement, a parameter promoted by proponents of passive troppo design. On the other is the need to reduce hot and very humid air, which even when moving across human skin can still be within what is normally considered to be the heat stress zone. In short, this is the difference between a porous building envelope that embraces prevailing breezes and a less permeable building that is more efficient at mechanical cooling. For the second half of the twentieth century, the response to the northern tropical climate has shifted from passive design to active cooling through air conditioning. This shift helped displace the traditional Queenslander, a high-set timber house with breezy undercroft spaces, 
casement windows to direct breezes and large verandas for shade and outdoor living. Air-conditioned residential suburbs are now dominant in Northern Australia and houses tend to look much like they do elsewhere, with high thermal mass, high embodied energy, limited shading and the active elimination of natural ventilation. These are not buildings designed with tropical liveability in mind.

Given the increasing attention directed towards Northern Australia due to its potential for growth, proximity to Asia and specialised expertise in tropical development, urban issues must be a pivotal part of any northern development strategy. Unfortunately, that has not been the case in the most recent green paper on northern development (Australian Government, 2014). This chapter puts urban growth in the context of a developing tropical Australia, where an increase in the number of residential detached buildings will contribute to mounting energy demands and greenhouse emissions unless more regionally responsive/climate sensitive subdivision designs are advocated for the region. Although the chapter sets out some of these challenges, it also provides case studies of innovation in the field, arguing that efforts to provide climatically adapted design will make new suburban development more liveable for growing populations in a growing Northern Australia.

\section{Challenges to Liveability in Tropical Australia}

Our research focus is to work from design principles that seek to manage thermal comfort at the scale of individual buildings and precincts in ways that are also cognisant of wider sustainability and liveability concerns including energy, water, resource depletion, amenity and biodiversity. To do that, we need to understand the basic drivers of thermal comfort. Thermal conditions in urban areas are influenced by many factors, including building designs and materials, and the type and amount of urban vegetation (Emmanuel, 2005). These factors combine to create urban heat islands (UHI) where temperatures can be $4^{\circ} \mathrm{C}$ higher than in less built-up areas, sometimes leading to increases in heat stress-related morbidity and mortality (Wong \& Yu, 2005; Loughnan et al., 2013; Bi et al., 2011). Architects and urban designers can apply different design techniques to mitigate these heat stress conditions, but environmentally 
responsive, tropical architecture has tended to recede in the face of modernising cities where international building styles are constructed from materials travelling long distances.

Many scholars and practitioners stress the importance of passive cooling techniques in tropical building design, including the layout of buildings but also the urban design techniques that affect human thermal conditions in tropical places more generally (Baker, 1987; Givoni, 1992; Aynsley, 2006; Cheng et al., 2007; Yilmaz, 2007; Kibert, 2012). The environment in and around any building can be enhanced through design elements such as good orientation for shading and capturing prevailing winds, creating enough distance between buildings to enable breezeways and vegetation for shade, using appropriate building forms that enable good ventilation (both from external breezes and also ceiling fans) and selecting building materials with appropriate thermal mass for the site. In addition to design techniques at the individual building scale, the layout, geometry, material and density of buildings within the wider urban fabric can contribute to increased air temperatures by storing heat and preventing natural ventilation, while parks and other green areas play a crucial role in reducing the impact of UHI at a local level (Ali-Toudert \& Mayer, 2007; Bowler et al., 2010; Shashua-Bar et al., 2012). Urban designers can mitigate heat stress by addressing these issues, using appropriate building and surface materials and considering the cooling effects of green spaces on urban ambient temperatures.

Designing lots and subdivisions that minimise solar radiation and allow access to prevailing breezes is considered a major factor in improving the thermal performance of a residential housing. Lot layout in particular is crucial to the thermal performance and energy efficiency of a building envelope (Miller \& Ambrose, 2005; CRCCI, 2006; Ambrose, 2008). Miller and Ambrose (2005) considered the influence of lot orientation on the energy efficiency of buildings' envelope in the subtropics, for example, and found that changing the orientation of the house can increase or decrease the energy load by 10-32 per cent. In 2006, the CRCCI carried out a related study of the role of natural ventilation in cooling South-east Queensland houses. The study found that the small lots (18-25 m deep) had very poor cross-flow ventilation and that energy efficiency was harder to achieve in houses built on these lots because of the ratios of lot area to building floor area.

These design techniques notwithstanding, there is no agreed way to measure the effectiveness of mitigation strategies. But measuring thermal comfort is important because of the very small margin between the upper 
limit of comfort and the 'onset of heat stress' in the tropics (Aynsley, 1997, p. 168). Two widely used thermal comfort prediction methods in the academic literature include the Predicted Mean Vote (PMV) (developed by Fanger, 1986) and the Adaptive Model (AM) (Auliciems \& Szokolay, 1997; de Dear \& Brager, 1998; Humphreys \& Fergus Nicol, 2002). The PMV index is calculated by using variables such as the metabolic rate and clothing type of survey participants, the internal air temperature and the radiant temperature and relative humidity and velocity of the air. However, the PMV method has been criticised as inappropriate for predicting thermal comfort in naturally ventilated buildings. De Dear and Brager (1998) suggested that the AM better predicts thermal comfort because it considers outdoor temperature, behavioural adjustment, physiological acclimatisation and psychological habitation or expectation. Halawa and Van Hoof (2012) suggested the development of a new method that would incorporate the best of the PMV and AM.

In a policy context, Australia's National House Energy Rating System (NatHERS) has adopted the far simpler Effective Temperature (ET*) index for assessing indoor thermal comfort. NatHERS is a national framework regulating thermal performances of Australian homes and encourages energy-efficient building design and construction by providing a reliable way to estimate and rank the potential thermal performance of residential buildings. The ET* index adopted by NatHERS is a dry bulb temperature of a uniform enclosed space at 50 per cent relative humidity, 'which would produce the same net heat exchange by radiation, convection and evaporation as the environment in question' (Auliciems \& Szokolay, 1997, p. 36). According to NatHERS, active cooling is required if indoor temperature is over the upper limit of neutral temperature range; in the tropical climate zones of Darwin and Cairns, this upper limit is $26.5^{\circ} \mathrm{C}$ (NatHERS, 2014).

Research on thermal comfort in a hot and humid tropical climate such as Darwin shows that passive design techniques alone cannot significantly reduce indoor temperature and humidity levels, but increased ventilation can help improve thermal comfort more generally (Kane et al., 2009). Kane et al. (2009) used TRNSYS energy simulation software to simulate 24-hour ventilation, night-only ventilation and insulation and shading in lightweight elevated and concrete houses. Their research suggested an upper limit of thermal comfort at $29.3^{\circ} \mathrm{C}$ with 90 per cent satisfaction during the January-March period - a temperature higher than that suggested by the NatHERS rating scheme. During the measurements for 
the study, the outdoor temperature reached a maximum of $35.5^{\circ} \mathrm{C}$ with a relative humidity of 91.5 per cent. In the completely closed concrete house the indoor temperature reached $32.4^{\circ} \mathrm{C}$ in the living room and $36.2^{\circ} \mathrm{C}$ in the bedroom, with 76.9 per cent and 82.4 per cent relative humidity respectively. Indoor maximum temperature and relative humidity in the open elevated house reached $36.5^{\circ} \mathrm{C}$ and 79.6 per cent in living room, and $34.5^{\circ} \mathrm{C}$ and 82.6 per cent in bedroom. In other words, Darwin's overnight temperature and humidity are too high during the warm months for design techniques such as shading and insulation to make sufficient impact.

Passive design for the hot and humid tropics focuses mainly on addressing heat, and seems to overlook the oppressive northern humidity, especially in the 'Build Up' and monsoon seasons. Ventilation and shading alone are insufficient to maintain thermal comfort for most people during the seasonal rains. Conversely, designing dwellings so that the air conditioning works efficiently in extreme heat and humidity has to date resulted in buildings that are relatively inefficient and unsustainable over the whole year.

Research on human thermal comfort in the hot and humid Australian tropics is sparse, with only a few studies of indoor comfort and no published research on outdoor conditions in the wider urban environment. There is also very little research about relative senses of thermal comfort, which might be especially relevant as the towns and cities of Northern Australia grow and bring new migrants from different climate zones (see Oppermann et al., 2017, for a critical review of tropical heat). For example, Kenawy and Elkadi's (2013) research in Melbourne showed some correlation between cultural and climatic background and experiences of heat stress, which has implications for human thermal comfort in both indoor and outdoor spaces (see also Hansen et al., 2013). These gaps in research, combined with the Northern Australia development agenda, inspired us to share two case studies of innovation in the field of tropical design. The first is a project that evolves criteria for assessing good design in the tropics, highlighting examples from the Far North Queensland region. The second is a residential precinct in suburban Darwin that implements passive design features at the neighbourhood and individual lot level. These case studies emphasise design principles that shape thermal comfort, while at the same time keeping in sight a broader sustainability/liveability agenda. 


\section{Case Study 1: Tropical Design Case Studies Project}

The first case study is a joint initiative of the Tropical Green Building Network (TGBN) and James Cook University (JCU) that aims to document and share the knowledge and best-practice tropical expertise in the built environment in tropical north Queensland (see JCU, 2018). The TGBN/JCU case studies record key features of selected sustainable/ green/tropically adapted building projects in the region, from large projects to domestic homes, including work carried out in national parks, tourist accommodation, multi-units and in remote Aboriginal communities. Several of the projects already have green star ratings from various sources, but other projects are well adapted to the tropical environment but are difficult to rate using criteria typically based on temperate models (see Figure 20.2). The project's aim was to consolidate existing knowledge and expertise and develop a vocabulary of features that work well in a tropical environment.

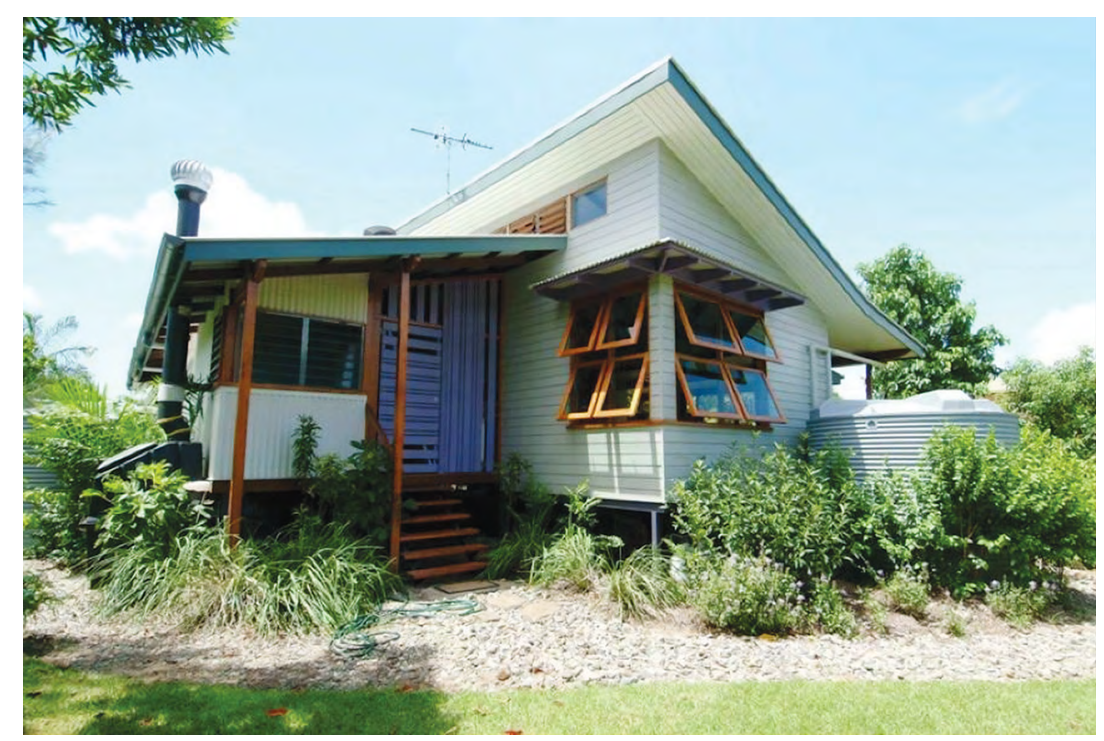

Figure 20.2: Sunbird House.

Note: The Sunbird house uses passive design for shade and natural ventilation and renewable energy use, with sustainably sourced materials for durability and low maintenance in the tropical climate. Its porous building envelope is not encouraged by rating software, even though it enables the natural ventilation that enhances thermal comfort for most of the year.

Source: JCU (2018). 
The case studies were developed through consultation with a working group of industry experts, mostly architects but also engineers, planners and others involved in the construction industry. The group acknowledged that rating tools had not been particularly effective in providing good outcomes for tropical sustainable design, so the project evolved specific criteria for defining what constitutes good tropical outcomes. The working group drew on the current Australian rating, accreditation and approval systems underpinned by codes and standards for sustainable construction and supplemented this with a working knowledge of building in tropical, regional Australia. Through the process the group created a standardised set of sustainability criteria that enabled comparison across different types - residential, commercial, industrial, civil, civic and retrofitted/ renovated buildings. The group helped prepare a guiding document and data collection sheet that could be distributed to those in industry practising good tropical design.

The group identified common criteria and categories to define what was important in each from a regional, tropical perspective. In total, the criteria provided information on the content of six primary focus areas of sustainable tropical design that were deemed critical—planning and management, site, design, materials, energy and water. Through this process, the research revealed that tropical sustainable design expertise is about planning for tropical wet/dry seasonality; using passive design for good solar orientation and capturing breezes; developing and applying building materials and technologies for extreme heat, cyclones, humidity and heavy rainfall; and encouraging sustainable environmental practices through the efficient use of renewable natural resources and the protection of natural assets.

While the case studies focus on a wider range of building/development types beyond suburban development, many examples of good tropical residential design are documented that might not score well with current ratings software. Although ratings tools are fast evolving with feedback from different sectors, they often privilege fully sealed buildings with a high thermal mass, rather than the more desirable lightweight construction with a porous building envelope that enables good ventilation in tropical climates. In other words, they tend to further entrench the increasingly ubiquitous concrete block home with concrete slabs (colloquially known as 'eskies'). Block homes are favoured by the project home market, and while they may be more efficient at retaining air conditioning for a few months of the year, it is also possible they 
increase the number of days climate control is used in tropical Australian towns and cities. More research in the field is clearly needed, and the TGBN/JCU case studies project aims to inspire more research in the field of tropical design.

\section{Case Study 2: Breezes Muirhead as Sustainable Subdivision}

Another case study worthy of discussion is a residential development in suburban Darwin, Breezes Muirhead. Located in in Darwin's northern suburbs, the developer Defence Housing Australia (DHA) in partnership with Investa has aimed to deliver an environmentally responsive master planned community. The development is designed to strategically optimise the cooling impact of year-round sea breezes, dry season southeasterly trade winds and wet season westerly, north-westerly winds. This was achieved by orienting the master plan to enable maximum cross ventilation of each home and to ensure the penetration of breezes throughout the development. This model challenges standard master planning practice in terms of solar access and lot orientation.

The low density master plan design includes extensive open green space, parklands and neighbourhood pocket parks, staggered blocks and a street layout that provides for the movement of prevailing cool breezes through the subdivision. The orientation and width of lots and a specifically designed breezeway (see Figure 20.3) are designed to provide access to breezes for all houses in the development. The Breezes Muirhead Design Guidelines for house builders outlines the requirements and recommendations that should be reflected in the proposed plans submitted to the Breezes Muirhead Design Review Panel for approval. Requirements include roof colours, size of rooms, cross ventilation for main living areas and deep eaves.

To ensure the penetration of breezes throughout the development, design guidelines control fencing and landscaping and dictate window locations and room span. To prevent the obstruction of cool breezes the guidelines also require a $4.5 \mathrm{~m}$ site setback (see Figure 20.4), minimum $50 \mathrm{~m}^{2}$ of open space, pool type or slat fencing and the use of particular vegetation specified in the document. 


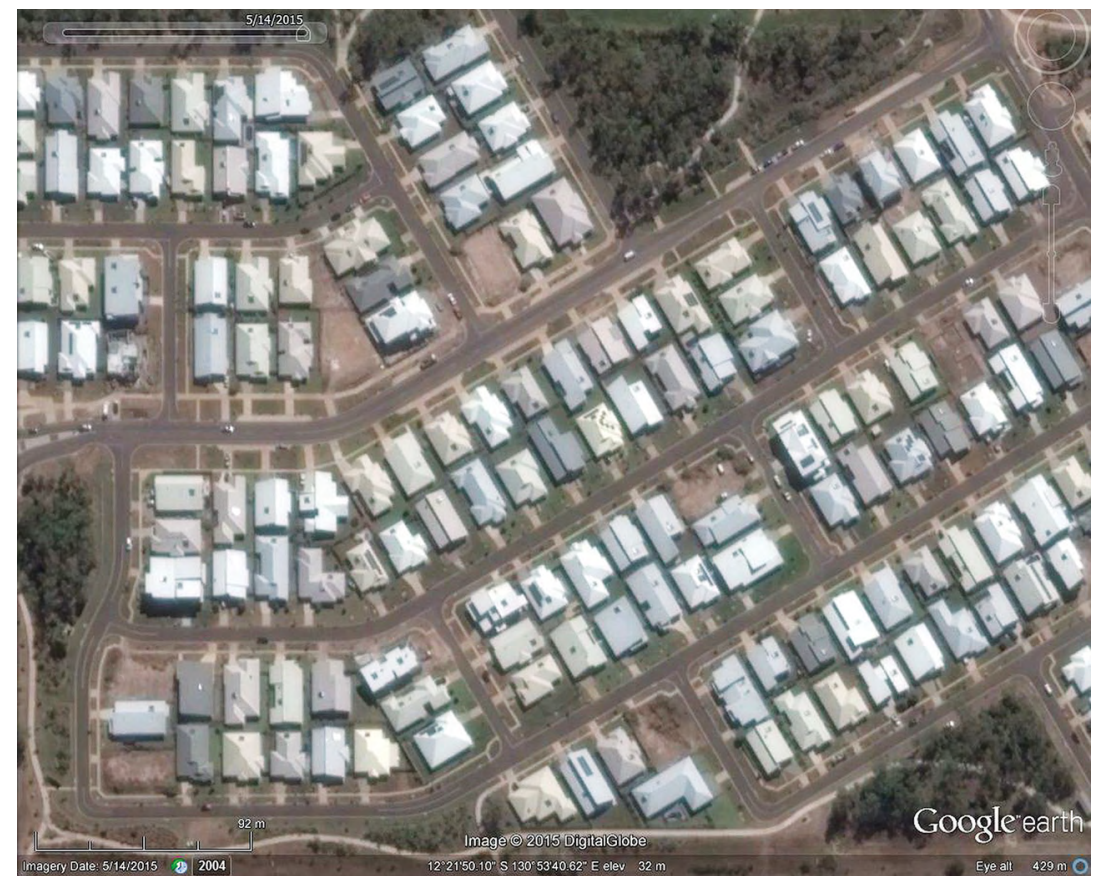

Figure 20.3: Google Earth image of Breezes Muirhead (24 April 2015).

Note: When compared to the subdivision in Figure 20.1, this neighbourhood has larger setbacks, more footpaths, lighter roof colours and more open space.

Source: Google Earth.

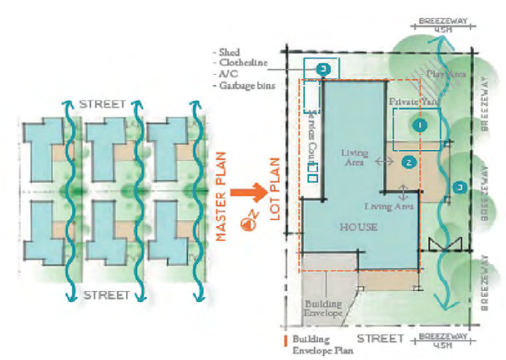

Figure 20.4: Requirement for breezeway provision.

Source: Defence Housing Australia (2016).

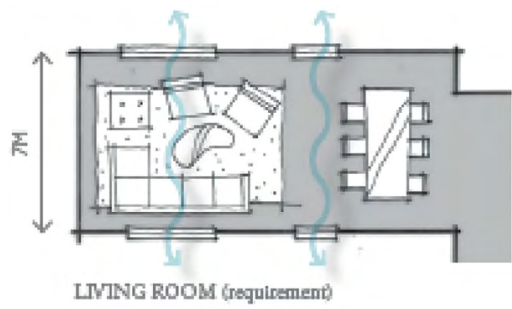

Figure 20.5: Provision for cross ventilation.

Source: Defence Housing Australia (2016).

To ensure building cross ventilation the guidelines require designing at least one room with windows situated parallel to each other and having 50 per cent of louvres on the front facade out of total window area (see Figure 20.5). The guidelines also regulate roof and wall colour to increase the effect of albedo and reduce the heat radiation from the building surface. 
In this way, Breezes Muirhead is an experiment in tropical urban design, drawing on ideas of best practice. With the subdivision soon due for completion there is an opportunity to assess how this new master planned development mediates urban thermal comfort for its residents. The authors are collaborating on a project with Investa, DHA and Power and Water Corporation NT to do just that.

\section{Conclusion}

Current building rating systems assume that air conditioning is essential in tropical conditions and, thus, favour buildings designed to ensure that air conditioners work efficiently. They do not favour buildings or precincts designed to minimise the use of air conditioning in number of days per year and number of hours per day through maximising ventilation, shading and green space. There are compelling arguments for a renewed focus on design for sustainability in tropical built environments in Northern Australia. Good design increases the liveability of urban areas but also minimises energy use and net greenhouse gas emissions, making maximum use of natural and recyclable materials, retaining water within urban landscapes and improving the quality of run-off. The hot and humid climate poses a serious design challenge to deliver thermal comfort and improve sustainability. Research is underway to critically assess the best design approach for this climate, and there are likely to be useful lessons in/for the countries to our north.

\section{References}

Adams, R. (2011, 4 October). Creating places for people: The Melbourne experience [Video file]. Retrieved from www.youtube.com/watch?v=lfnynzD0yDI

Ali-Toudert, F. \& Mayer, H. (2007). Thermal comfort in an east-west oriented street canyon in Freiburg (Germany) under hot summer conditions. Theoretical and Applied Climatology, 87(1-4), 223-237.

Ambrose, M. (2008). Energy-efficient housing and sub-division design. In P. Newton (Ed.), Transitions: Pathways toward sustainable urban development in Australia (pp. 425-435). Melbourne, Vic.: CSIRO.

Auliciems, A. \& Szokolay, S. V. (1997). Thermal comfort: Passive and low energy architecture. Brisbane, Qld: Department of Architecture, University of Queensland. 
Australian Government. (2014). Green paper on developing Northern Australia. Canberra, ACT: Department of the Prime Minister and Cabinet. Retrieved from www.industry.gov.au/sites/default/files/2019-09/green-paper-on-developingnorthern-australia.pdf

Aynsley, R. M. (1997). Tropical architecture: The future. In Proceedings of the ANZAScA conference (pp. 167-175). The Australian and New Zealand Architectural Science Association.

Aynsley, R. (2006). Indoor wind speed coefficients for estimating summer comfort. International Journal of Ventilation, 5(1), 3-12.

Baker, N. V. (1987). Passive and low energy building design for tropical island climates. London, England: Commonwealth Secretariat.

Bay, J.-H. \& Ong, B.-L. (2006). Tropical sustainable architecture: Social and environmental dimensions. Oxford, England: Architectural Press.

Bi, P., Williams, S., Loughnan, M., Lloyd, G., Hansen, A., Kjellstrom, T., ... Saniotis, A. (2011). The effects of extreme heat on human mortality and morbidity in Australia: Implications for public health. Asia-Pacific Journal of Public Health, 23(2), 27S-36S.

Bowler, D. E., Buyung-Ali, L., Knight, T. M. \& Pullin, A. S. (2010). Urban greening to cool towns and cities: A systematic review of the empirical evidence. Landscape and Urban Planning, 97(3), 147-155.

Cheng, V., Ng, E. \& Givoni, B. (2005). Effect of envelope colour and thermal mass on indoor temperatures in hot humid climate. Solar Energy, 78(4), 528-534.

Cooperative Research Centre for Construction Innovation (CRCCI). (2006). The role of natural ventilation in building sustainable subdivisions in south east Queensland. Brisbane, Qld: CRCCI. Retrieved from eprints.qut.edu.au/27032

de Dear, R. \& Brager, G. S. (1998). Developing an adaptive model of thermal comfort and preference. Center for the Built Environment, UC Berkeley. Retrieved from escholarship.org/uc/item/4qq2p9c6

Defence Housing Australia. (2016). Breezes Muirhead: Design guidelines. Retrieved from www.breezesmuirhead.com.au/assets/uploads/2018/05/Breezes_Design_ Guidelinesweb.pdf

Emmanuel, M. R. (2005). An urban approach to climate-sensitive design: Strategies for the tropics. London, England; New York, NY: Spon Press. 
Emmanuel, R. (1995). Energy efficient urban design guidelines for warm-humid cities: Strategies for Colombo, Sri Lanka. Journal of Architectural and Planning Research, 12(1), 58-79.

Fanger, P. O. (1986). Thermal environment-human requirements. Environmentalist, 6(4), 275-278.

Givoni, B. (1992). Climatic aspects of urban design in tropical regions. Atmospheric Environment. Part B. Urban Atmosphere, 26(3), 397-406.

Halawa, E. \& Van Hoof, J. (2012). The adaptive approach to thermal comfort: A critical overview. Energy and Buildings, 51, 101-110.

Hall, A. C. (2010). The life and death of the Australian backyard. Collingwood, Vic.: CSIRO Publishing.

Hansen, A., Bi, L., Saniotis, A. \& Nitschke, M. (2013). Vulnerability to extreme heat and climate change: Is ethnicity a factor? Global Health Action, 6, 1-7.

Humphreys, M. A. \& Fergus Nicol, J. (2002). The validity of ISO-PMV for predicting comfort votes in every-day thermal environments. Energy and Buildings, 34(6), 667-684.

James Cook University. (2018). Tropical sustainable design case studies. Retrieved from www.jcu.edu.au/TUDLab/research-projects/tropical-sustainable-designcase-studies

Kane, A., Fuller, R. J., Luther, M. B. \& Boldys, R. (2009). Improving comfort levels in Darwin houses through passive design. In ANZSES 2009: Proceedings of Solar 2009, the 47th ANZSES annual conference (pp. 1-10). Brisbane, Qld: Pictorial Press Australia in conjunction with Impress Media Brisbane.

Kenawy, I. \& Elkadi, H. (2013). The impact of cultural and climatic background on thermal sensation votes. In PLEA 2013: Proceedings of the 29th sustainable architecture for a renewable future conference (pp. 1-6). Munich, Germany: Technische Universität München and PLEA Organization.

Kibert, C. J. (2012). Sustainable construction: Green building design and delivery. Hoboken, NJ: Wiley.

Law, L. (2019). The tropical backyard: Performing environmental difference. Geographical Research, 57(3), 331-343.

Loughnan, M. E., Tapper, N. J., Phan, T., Lynch, K. \& McInnes, J. A. (2013). A spatial vulnerability analysis of urban populations during extreme heat events in Australian capital cities. National Climate Change Adaptation Research Facility, Gold Coast. Retrieved from nccarf.edu.au/wp-content/uploads/ 2019/03/Loughnan_2013_Spatial_vulnerability_analysis.pdf 
Miller, A. \& Ambrose, M. (2005). Sustainable subdivisions: Energy-efficient design report to industry. CRC for Construction Innovation. Retrieved from eprints. qut.edu.au/27250/1/27250.pdf

National House Energy Rating System (NatHERS). (2014). Occupancy settings. Department of Industry.

Oppermann, E., Brearley, M., Law, L., Smith, J. A., Clough, A. \& Zander, K. (2017). Heat, humidity and health in Australia's tropical monsoon zone: A critical review of heat stress in a changing climate. WIREs Climate Change, $8(4), 1-23$.

Safarova, S., Garnett, S., Halawa, E., Law, L., van Hoof, J. \& Trombley, J. (2018). Sustainable urban design and energy consumption of households in the hot and humid tropical climate of Darwin. In W. L. Filho, J. Rogers \& U. Iyer-Raniga (Eds), Sustainable development research in the Asia-Pacific region: Education, cities, infrastructure and buildings (pp. 421-435). Switzerland: Springer.

Safarova, S., Halawa, E., Campbell, A., Law, L. \& van Hoof, J. (2017). Pathways for optimal provision of thermal comfort and sustainability of residential housing in hot and humid tropics: A critical review. Indoor and Built Environment. doi.org/10.1177/1420326X17701805

Shashua-Bar, L., Tsiros, I. X. \& Hoffman, M. (2012). Passive cooling design options to ameliorate thermal comfort in urban streets of a Mediterranean climate (Athens) under hot summer conditions. Building and Environment, 57, 110-119.

State of the Environment 2011 Committee. (2011). Australia state of the environment 2011. Canberra, ACT: Department of Sustainability, Environment, Water, Population and Communities.

United Nations. (2014). World urbanization prospects: The 2014 revision, highlights (UN Document ST/ESA/SER.A/352). Department of Economic and Social Affairs, Population Division.

Weller, R. \& Bolleter, J. A. (2013). Made in Australia: The future of Australian cities. Perth, WA: UWA Publishing.

Wong, N. H. \& Yu, C. (2005). Study of green areas and urban heat island in a tropical city. Habitat International, 29(3), 547-558.

Yilmaz, Z. (2007). Evaluation of energy efficient design strategies for different climatic zones: Comparison of thermal performance of buildings in temperatehumid and hot-dry climate. Energy and Buildings, 39(3), 306-316. 
This text is taken from Leading from the North: Rethinking Northern Australia Development, edited by Ruth Wallace, Sharon Harwood, Rolf Gerritsen, Bruce Prideaux, Tom Brewer, Linda Rosenman and Allan Dale, published 2021 by ANU Press, The Australian National University, Canberra, Australia.

doi.org/10.22459/LN.2021.20 